\section{СПИСОК ВИКОРИСТАНОЇ ЛІТЕРАТУРИ}

1. Амонашвили Ш. А. Размышления о гуманной педагогике / Ш. Амонашвили. - М. : Издательский Дом Шалвы Амонашвили, 1996. - 496 с.

2. Барабаш О. Педагогіка партнерства - сучасний тип взаємодії між учасниками освітнього процесу / О. Барабаш // Учитель початкової школи. - 2018. № 8. - C. 3-7.

3. Вертипорох О. Школа-простір освітніх можливостей / О. Вертипорох, М. Ніщенко // Рідна школа. 2017. - № 7/8. - С. 59-61.

4. Грошева О. Готуємося до НУШ: співучителювання / О. Грошева, М. Грішак // Початкова школа. 2019. - № 1. - С. 62.

5. Денисюк Л. Інноваційна модель «Школа трансформаційного лідерства» / Л. Денисюк // Рідна школа. - 2017. - № 7/8. - С. 62-64.

6. Карло Т. Створюємо Школу громадського партнерства / Т. Карло // Рідна школа. - 2017. № 7/8. - C. 36-39.

7. Ніколенко Л. Педагогіка партнерства як умова реалізації завдань розвитку особистості дитини у контексті Нової української школи / Л. Ніколенко. URL: http://lib.iitta.gov.ua/710749/1//Ніколенко_Методист Ст.\%20Педаг.\%20партнерства\%20як\%20умова. pdf (дата звернення: 11.11.2019).

8. Лысенкова С. Педагогика сотрудничества / С. Лысенкова, В. Шаталов, И. Волков и др. // Учительская газета. - 1986. - 18 октября.

9. Рагулько О. Педагогіка співробітництва - сучасна педагогічна технологія формування особистості учня / О. Рагулько // Матеріали I Всеукраїнської науково-практичної інтернет-конференції «Педагогічна персоналістика: теорія, історія, освітня практика». - 2015. - С. 49-55. - URL: https://conference.pu.if. ua/forum/files/25022016/zbirnyk.pdf (дата звернення: 05.12.2019).

10. Савченко С. В. Педагогіка партнерства у проекті Концепції «Нової української школи» / C. В. Савченко. URL : https://www.slideshare.net/ippokubg/ss-67119769 (дата звернення: 11.12.2019).

11. Стрельніков В. Ю. Педагогічні основи забезпечення особистісного і професійного розвитку студентів засобами інноваційних технологій навчання / В. Ю. Стрельніков. - Полтава : РВ ПУСКУ, 2002. Кн. 2. -230 с.

12. Сухомлинський В. О. Вибрані твори : в 5 т. / В. О. Сухомлинський. - К. : Радянська школа, 1976. T. 2. $-670 \mathrm{c}$.

13. Тирон В. О. Студактивне заняття як одна із форм самостійної роботи студентів / В. О. Тирон. URL: https://vseosvita.ua/library/studaktivne-zanattaak-odna-z-form-samostijnoi-roboti-studentiv-177791. html (дата звернення: 05.12.2019).

14. Чорноус Н. А. Навчальне співробітництво: історичний аспект / Н. А. Чорноус // Педагогіка формування творчої особистості у вищій і загальноосвітній школах. - 2014. - Вип. 36. - С. 64-68.

15. Янова В. М. Педагогіка співробітництва: сутність, ключові ідеї, форми та методи URL: http:// ru.osvita.ua/school/lessons summary/upbring/31097/ (дата звернення: 05.12.2019).

Дата надходження до редакиіï: 28.12.2019 р.

\section{Юлія ГЛІНЧУК,}

кандидат педагогічних наук, доцент кафедри загальнотехнічних дисичилін, технологій та иивільної безпеки

Рівненського державного гуманітарного університету

\title{
ЗДОРОВ'ЯЗБЕРІГАЮЧИЙ УРОК В ОСВІТНЬОМУ ПРОСТОРІ СЬОГОДЕННЯ
}

У статті наголошується на актуальності здоров'язбереження учнів. Зауважується значущість проблеми здоров'язберігаючого уроку. Здійснюється загальний огляд означеного питання на основі аналізу науково-методичних джерел та практики діяльності закладів загальної, вищої та післядипломної педагогічної освіти. Зазначається, щзо представлені погляди дослідників дають змогу окреслити основні критерії здоров'язберігаючого уроку, однак оцінювання ефективності уроку з позииій здоров'язбереження має місие лише в поодиноких закладах загальної середньої освіти. У закладах вищої та післядипломноі педагогічної освіти питанню здоров'язбереження учнів під час уроку належна увага не приділяється.

Ключові слова: здоров'я, учні, здоров'язберігаючий урок, критерії.
В статье отмечается актуальность здоровьесбережения школьников. Подчеркнуто значимость проблемы здоровьесберегающего урока. Проведено общчее рассмотрение обозначенного вопроса на основе анализа научно-методических источников и практики деятельности заведений общего, высшего и последипломного педагогического образования. Указано, что приведенные взгляды исследователей позволяют очертить основные критерии здоровьесберегающего урока, но оценивание эффективности урока с позичий здоровьесбережения имеет место лишь в одиночных заведениях общего образования. В учреждениях высшего и последипломного педагогического образования вопросу здоровьесбережения учашихся не уделяется нужное внимание.

Ключевые слова: здоровье, ученики, здоровьесберегающий урок, критерии. 
The loss of health for students during their schooling is a nationwide problem to date. The factors that aggravate it are the unfavorable demographic situation, active labor migration of working-age population and tense sociopolitical environment.

The main form of general education organization is a lesson. Unfortunately, for the most part, it is during the lesson that the primary health loss of the students occurs. Because of this, the issue of preserving students' health during the lessons is important for both the general, higher education and postgraduate education systems. Students in pedagogical specialties should acquire competence in organizing a health lesson and identify and improve it in future professional activities at an appropriate level.

The purpose of this article is to provide an overview of the issue of the health lesson based on the analysis of scientific and methodological sources and practice of the institutions of general, higher pedagogical and postgraduate teacher education.

Analysis of the sources of the problem under study suggests that this issue is not overly enlightened in the scientific and methodological literature. However, the views of the researchers allow us to outline the basic criteria for a health lesson.

Assessing the effectiveness of a health lesson is only available in selected general education institutions.

Higher education and postgraduate education do not pay much attention to the health of students during the lesson.

We believe that, in the context of the strategic nature of the problem identified, the level of health of students during lessons in general education institutions, the preparation of students of pedagogical specialties for the health of students during lessons in institutions of higher pedagogical education, and the development of teachers' qualifications for the safety of students during health education are striking markers of the quality of the education system.

Key words: health, students, health lesson, criteria.

Постановка проблеми. На сьогодні проблема втрати здоров'я школярами внаслідок дії негативних освітніх чинників набула статусу загальнонаціональної небезпеки. Чинниками, що пї посилюють, $\epsilon$ несприятлива демографічна ситуація, активна трудова міграція працездатного населення та напружена соціально-політична обстановка.

Провідною формою організації загальної середньої освіти є урок. На жаль, здебільшого саме під час уроку відбувається основна втрата здоров'я школярів. У зв'язку з цим питання збереження здоров'я учнів під час уроків $є$ важливим не лише для системи загальної середньої, а й вищої та післядипломної педагогічної освіти. Вважаємо, що студенти педагогічних спеціальностей мають оволодіти компетентністю щодо організації здоров'язберігаючого уроку і на належному рівні виявляти та вдосконалювати їі в майбутній професійній діяльності.

Аналіз наукових досліджень і публікацій. Незважаючи на декларованість ідей збереження здоров'я підростаючого покоління у провідних освітянських документах, сьогодні відбувається стрімка його втрата, пік якої припадає саме на період шкільного навчання. Адже, як правильно зауважує Ю. Гнатюк, у зв’язку з недотриманням основних умов організації навчального процесу зростає частота гострих, небезпечних для життя та хронічних захворювань у школярів, порушення постави, зниження гостроти зору, дидактогенні, психічні та соматичні розлади тощо [4].

Ми переконані, що шкільний учитель не повинен жити одним днем, обмежуючись системою «урок - засвоєння навчального матеріалу - оцінка», він має мислити системно і масштабно, зважаючи на те, як вплине щоденний шкільний досвід учня на його подальше життя та здоров'я. У контексті цього погоджуємося 3 думкою О. Філіпп’євої, що докорінні зміни стилю життя із приходом до школи, нові вимоги, нове соціальне середовище та особливо перші негаразди у процесі навчання часто створюють стресову ситуацію для дитини, наслідки якої можуть виявлятися впродовж усього життя [10].

Думку про те, що нині за період навчання у школі учні не лише отримують знання, а й втрачають своє здоров'я, висловлює й Л. Демінська [5]. Аналогічних поглядів дотримується і Т. Бережна, яка вважає, що традиційна система освіти більшою мірою орієнтована на здобуття знань, інформації та недостатньо - на формування здоров'язбережувального середовища [2].

Метою статті є загальний огляд питання здоров'язберігаючого уроку на основі аналізу науково-методичних джерел та практики діяльності закладів загальної, вищої та післядипломної педагогічної освіти.

Виклад основного матеріалу. Здоров'язберігаючий урок, переконані О. Попов, С. Лупаренко та Л. Бойко, - це форма організації навчання, яка забезпечує дитині та вчителю збереження й підвищення запасу їхніх життєвих сил від початку до кінця уроку [6].

Критеріями здоров'язберігаючого уроку Л. Тихомирова називає: наявність фізкультхвилинок; дотримання температурного режиму, режиму вологості, провітрювання; стиль спілкування, наявність або відсутність психотравмуючих ситуацій, рівень працездатності учнів, а також сприятливий емоційний настрій [9]. Позитивно оцінюємо критерії здоров'язберігаючого уроку, які наводить Ю. Багно [1], грунтуючись на сутності здоров'язберігаючих технологій (за О. Ващенко [3]):

- санітарно-гігієнічні: санітарно-гігієнічний режим (провітрене приміщення, чиста та зволожена підлога, відсутність пилу на підвіконнях, наявність кімнатних рослин, чиста дошка); освітлення та температура згідно з відповідними санітарно-гігієнічними вимогами; оснащеність уроку необхідним обладнанням, його задовільний стан; відсутність монотонних звукових подразників; тривалість застосування технічних засобів навчання та інтернет-ресурсів відповідно до санітарно-гігієнічних вимог; 
- організачійно-навчальні: чергування різних видів навчальної діяльності учнів; оптимальний розподіл навчального матеріалу та доцільність навантаження учнів протягом уроку; профілактика втоми завдяки оптимальному поєднанню фронтальних, групових та індивідуальних форм роботи учнів, зміна довільної та емоційної активності й розслаблення, чергування видів навчальної діяльності; застосування під час уроку фізкультхвилинок, масажних вправ, релаксаційних пауз, хвилин розслаблення 3 використанням музичного супроводу; диференційовані домашні завдання - їх обсяг, робочий ритм 3 урахуванням вікових та індивідуальних особливостей школярів, їх профільна спрямованість;

- психологічні: врахування вікових психологофізіологічних особливостей учнів; формування мотивації на досягнення успіху в навчанні (пояснення виконання завдань, підтримка зацікавленості та успіхів учнів учителем, надання взаємодопомоги); раціональне використання завдань, спрямованих на розвиток пам'яті, уваги, уяви, мислення, мовлення; оцінювання навчальної діяльності дітей шляхом порівняння досягнень учня не 3 іншими, а із ним самим; створення емоційно-позитивного клімату навчання (суб'єкт-суб'єктна взаємодія; наявність емоційних розрядок, добрих жартів, усмішок; використання гумористичних картинок, афоризмів, музичного супроводу тощо); застосування елементів музикотерапії, рухотерапії, аромотерапії, кольоротерапії, арттерапії тощо; вигляд учнів наприкінці уроку (відсутність втоми, висока працездатність, активність; урівноваженість психічного стану, усвідомлене ставлення до себе, адекватна оцінка своїх здібностей і можливостей інших, віра у свої сили, настанова на успіх у житті);

- навчально-методичні: зв'язок теми, мети, змісту уроку з життям і здоров'ям людини, наявність акцентів на здоров'язбереження; особистісна зорієнтованість уроку; спрямування уроку на розвиток життєвих навичок, компетентностей, цінностей; формування в учнів життєвої мотивації на здоров'я, ведення здорового способу життя; методи педагогічного впливу на учнів (оптимально - не менше трьох видів за урок: словесний, наочний, аудіовізуальний; самостійної, активної, інтерактивної діяльності тощо); наявність можливості вільного вибору в учнів (виду та способу навчальної діяльності, рівня складності завдань, способу взаємодії, доведення особистісної думки, самооцінки і взаємної оцінки результатів діяльності, самопізнання); наявність і застосування завдань різної складності з урахуванням особистісних можливостей учнів у навчальній діяльності; домашнє завдання з можливістю вибору різних рівнів його складності, коментування.

Наведені критерії корелюють із критеріями аналізу уроку з позицій здоров'язбереження, які наводить М. Смирнов:

- гігієнічні умови в класі: чистота, температура, свіжість повітря, раціональність освітлення класу і дошки, присутність (відсутність) монотонних чи неприємних подразників тощо. Від дотримання цих простих умов залежить стомлюваність учнів та ризик виникнення алергічних реакцій;
- кількість видів навчальної діяльності, шо використовуються вчителем: опитування учнів, письмо, читання, слухання, розповідь, робота з наочними посібниками, відповіді на запитання, розв'язування прикладів, завдань та ін. Нормою вважається від 4 до 7 різних видів діяльності впродовж уроку. Одноманітність уроку сприяє швидкій втомлюваності школярів. Водночас необхідно пам'ятати, що часта зміна одного виду діяльності на інший потребує від учнів додаткових адаптаційних зусиль, що теж спричинює втомлюваність;

- середня тривалість і частота чергування різних видів навчальної діяльності: орієнтовна норма $7-10 \mathrm{xB}$;

- число використовуваних учителем видів викладення матеріалу та їх чергування: словесний, наочний, аудіовізуальний, самостійна робота та ін. Норма - не менше трьох за урок, чергування - не пізніше, ніж через 10-15 хв;

- використання методів, ш⿻ сприяють активізації ініціативи та творчого самовираження учнів: методи вільного вибору, активні методи, методи, спрямовані на самопізнання і розвиток та ін.;

- уміння вчителя використовувати можливості показу відеоматеріалів з метою вирішення навчальних та виховних завдань

- пози школярів та їх чергування залежно від особливостей виконуваних робіт. Ступінь природності пози учнів під час уроку може слугувати хорошим індикатором психологічної дії вчителя, ступеня його авторитаризму: механізм здоров'яруйнівної дії вчителя полягає, зокрема, в тому, що школярі під час його уроків надміру напружені. Ця ситуація не лише різко підвищує рівень невротизації дітей, а й згубно відображається на їх характері;

- фізкультхвилинки та фізкультпаузи: норма на кожні 15-20 хв уроку по одній хвилині 3-4 вправи (із повторенням по 3-4 рази), а також емоційний клімат під час виконання вправ та наявність у школярів бажання їх виконувати;

- включення до змісту уроків питань, пов'язаних зі здоров'ям та здоровим способом життя: вміння вчителя виокремити та наголосити на питаннях, пов'язаних зі здоров'ям, $є$ одним із критеріїв його професіоналізму;

- наявність у школярів мотивації до навчальної діяльності nid час уроку: інтерес до занять, прагнення дізнатись якомога більше, задоволення від активності, інтерес до навчального матеріалу тощо;

- сприятливий психологічний клімат під час уроку, який також є одним із показників успішності його проведення: заряд позитивних емоцій, отриманих учнями та самим учителем, визначає позитивний вплив школи на здоров'я;

- домінуючий вираз обличчя вчителя: урок вважається неповноцінним, якщо на ньому не було емоційно-смислових розрядок - усмішок, доречних жартів, використання приказок, афоризмів, музичних елементів та ін.;

- момент появи втоми учнів та зниження їх пізнавальної активності: визначається в ході спостережень за зростанням рухових і пасивних відволікань школярів у процесі навчальної діяльності. 
Норма - не раніше, ніж за 5-10 хв до закінчення уроку;

- темп та особливості закінчення уроку: бажано, щоб завершення уроку було спокійним: учні мають можливість задати вчителю запитання, вчитель коментує завдання додому тощо;

- стан і вигляд учнів після закінчення уроку (як інтегральний показник ефективності проведеного заняття), а також вигляд учителя [8].

Уважаємо, що варта схвалення анкета для аналізу уроку з позицій здоров'язбереження А. Севрук та О. Юніної [7].

Однак аналіз практичної діяльності закладів загальної середньої освіти на основі власного досвіду роботи у школі та дослідження негативних виробничих чинників сучасного загальноосвітнього середовища дає змогу стверджувати, що здоров'язбережувальна робота вчителя лише в поодиноких таких закладах розглядається як складова оцінювання його компетентності, зокрема й у процесі проведення уроків. Це, безумовно, пов'язано 3 тим, що ефективність роботи $33 \mathrm{CO}$ оцінюється передусім за результатами ЗНО, наявності призерів олімпіад, діяльності організації «Пласт» тощо.

Водночас при цьому в школах працює покоління вчителів, які у процесі фахової підготовки за радянських часів цілеспрямовано не готувалися до здоров'язбереження учнів. Як наслідок - упродовж цього періоду відбулося зниження загального стану здоров'я підростаючого покоління та з'явилися нові небезпеки: учні стали менше рухатися, перебувати на свіжому повітрі, погіршилися екологія та якість продуктів харчування, у життя стрімко увірвалися інформаційні технології та ін. На жаль, незважаючи на це, наразі в закладах вищої освіти відбувається згортання навчання 3 охорони праці.

Досвід власного дворазового перебування на курсах підвищення кваліфікації та опитування 126 учителів, що мали досвід курсової підготовки в системі післядипломної освіти, свідчать про те, що й у закладах післядипломної педагогічної освіти проблемі здоров'язбереження учнів під час уроків не надається особливої уваги.

Висновки. Отже, у зв'язку із вищеозначеним можемо стверджувати, що, незважаючи на актуальність та стратегічну значущість, питання здоров'язберігаючого уроку не є надто широко висвітленим у наукових та методичних джерелах. Однак представлені погляди дослідників дають змогу окреслити основні критерії такого виду уроку.

Оцінювання ефективності уроку з позицій здоров'язбереження має місце лише в поодиноких закладах загальної середньої освіти. При цьому в закладах вищої та післядипломної педагогічної освіти питанню здоров'язбереження учнів під час уроку належна увага не приділяється.

Уважаємо, що в контексті стратегічності означеної проблеми рівень здоров'язбереження учнів під час уроків у закладах загальної середньої освіти, підготовка студентів педагогічних спеціальностей до здоров'язбереження учнів у закладах вищої педагогічної освіти та підвищення кваліфікації учителів із цього питання є яскравими маркерами якості системи освіти загалом.

\section{СПИСОК ВИКОРИСТАНОЇ ЛІТЕРАТУРИ}

1. Багно Ю. Формування здоров'язбережувальної компетентності майбутніх учителів у процесі вивчення педагогічних дисциплін / Ю. Багно // Ключові компетентності в моделі сучасного фахівця : зб. наук. пр. III Міжнародної науково-практичної конференції (29 лютого 2016 р.) : [у 2 ч.]. - Ч. 1. $279 \mathrm{c}$.

2. Бережна Т. І. Здоров'язбережувальні педагогічні технології - важлива складова здоров'язбережувального середовища загальноосвітнього навчального закладу / Т. І. Бережна // Наукові записки. - Ніжин : НДУ ім. Миколи Гоголя, 2014. - № 2. - С. 35-40. (Серія «Психолого-педагогічні науки»).

3. Ващенко О. Готовність учителя до використання здоров'язберігаючих технологій у навчально-виховному процесі / О. Ващенко, С. Свириденко // Здоров'я та фізична культура. - 2006. - № 8. C. 1-6.

4. Гнатюк О. В. Психолого-педагогічні засади збереження і зміцнення здоров'я учнів / O. В. Гнатюк. URL: http://www.rusnauka.com/17 APSN_2009/Psihologia/47486.doc.htm (дата звернення: 12.01.2020).

5. Демінська Л. О. Аналіз змісту й умов використання здоров'язберігаючих технологій у системі загальноосвітніх шкіл / Л. О. Демінська // Педагогіка, психологія та медико-біологічні проблеми фізичного виховання і спорту. - 2010. - № 11. - С. 23-26.

6. Попов О. І. Психолого-гігієнічна сутність, види та особливості здоров'язберігаючих технологій у дітей в умовах сучасного навколишнього середовища / О. I. Попов, С. Є. Лупаренко, Л. Т. Бойко // Довкілля та здоров’я. - 2011. - № 3. С. 73-76.

7. Севрук А. И. Здоровьесберегающий урок: концепция, технологии, мониторинг / А. И. Севрук, Е. А. Юнина // Школьные технологии. - 2004. № 2. - С. 200-208.

8. Смирнов Н. К. Анализ проведения урока с позиций здоровьесбережения / Н. К. Смирнов // Практика административной работы в школе. - 2005. № 8. URL: https://lyc507u.mskobr.ru/files/analiz_uroka_s_pozicii_zdorov_esberezheniya.pdf (дата звернення: 12.01.2020).

9. Тихомирова Л. Ф. Экспертный подход в здоровьесберегающей деятельности педагога / Л. Ф. Тихомирова // Школьные технологии. - 2003. № 3. - С. 191-194.

10. Філіпп'єва О. А. Підготовка майбутніх учителів початкових класів до валеологічного виховання учнів : автореф. дис. на здобуття наук. ступеня канд. пед. наук : спец. 13.00.04 «Теорія і методика професійної освіти» / О. А. Філіпп'єва. - Кіровоград, 2008. - 20 с.

Дата надходження до редакиіï: 14.01.2020 p. 